\title{
Fertility and life expectancy of the predator Supputius cincticeps (Heteroptera: Pentatomidae) exposed to sublethal doses of permethrin
}

\author{
TERESINHA V ZANUNCIO ${ }^{1}$, JOSÉ C ZANUNCIO ${ }^{1}$, JOSÉ E SERRÃO², RÔMULO S \\ MEDEIROS $^{1}$, TOBÍAS BM PINON ${ }^{1}$, CAMILLA AZ SEDIYAMA $^{1}$
}

\footnotetext{
${ }^{1}$ Departamento de Biologia Animal, Universidade Federal de Viçosa, 36571-000 Viçosa, State of Minas Gerais, Brasil.

2 Departamento de Biologia Geral, Universidade Federal de Viçosa, 36571-000 Viçosa, State of Minas Gerais, Brasil.
}

\begin{abstract}
The stinkbug Supputius cincticeps (Stål) (Heteroptera: Pentatomidae) can be found in agricultural and forest ecosystems feeding primarily on larvae of Coleoptera and Lepidoptera, where it can be exposed to insecticide applications. This study therefore aimed to evaluate the reproductive potential of ' $S$. cincticeps after exposition to sublethal doses of permethrin $\left(5.74 \times 10^{-3}, 5.74 \times 10^{-2}, 5.74 \times 10^{-1}, 5.74\right.$ and $\left.57.44 \mathrm{ppb}\right)$ through the use of a fertility life table. The development cycle of this predator was determined in order to calculate its net reproductive rate $\left(R_{0}\right)$, the infinitesimal $\left(r_{m}\right)$ and finite $(\lambda)$ rates of increase in addition to mean generation time $(\mathrm{T})$. The net reproductive (18.31), infinitesimal $\left(\mathrm{r}_{\mathrm{m}}\right)(0.050)$ and finite $(\lambda)(1.051)$ rates of increase were higher, while generation time (57.93 days) was shorter for $S$. cincticeps exposed to $5.74 \times 10^{-1} \mathrm{ppb}$ of permethrin than in the control. This indicates a higher rate of population increase of this predator when exposed to this permethrin dose.
\end{abstract}

Key terms: Asopinae, biological control, pyrethroids, reproduction

\section{INTRODUCTION}

Insects can be plant feeders (Lustosa et al., 1999), predators (Zanuncio et al., 2003), or parasitoids (Matos et al. 2004a,b) and they can transmit diseases (Contreras et al., 2002, Uzcanga et al., 2003).

Biological control is important in integrated management of Lepidoptera defoliators of eucalyptus, especially with predatory Pentatomidae of genera Podisus and Supputius (Pentatomidae: Asopinae) (Zanuncio et al., 1992, 1994). Supputius cincticeps (Stål) (Heteroptera: Pentatomidae) and other predators of this family can inhabit many agro-ecosystems, where the use of insecticides can limit its impact in biological control programs
(McPherson, 1982). This shows the necessity of using insecticides that are efficient against pests and safe to natural enemies including predators (Guedes et al., 1992; Zanuncio et al., 1993, 1998; Batalha et al., 1995; 1997; Picanço et al., 1996; Suinaga et al., 1996) and parasitoids in integrated pest management programs (Guedes et al., 1992). Pirethroids are efficient against defoliating caterpillars (Elliot et al., 1978) and selective to beneficial insects such as predatory Pentatomidae (Rajakulendran and Plapp, 1982; Pree and Hagley, 1985; Yu, 1988).

Sublethal doses of insecticides that are toxic at high levels may increase the performance of organisms, a process known as hormesis (Calabrese and Baldwin, 
1997a,b; Calabrese, 1999; Forbes, 2000), as reported for insects and mites of economic importance (Calabrese, 1999; Forbes, 2000) and for natural enemies (Zanuncio et al., 2003).

The effect of insecticides can be evaluated with fertility life tables that include estimates of parameters of population growth such as net reproductive rate $\left(\mathrm{R}_{0}\right)$, generation time $(\mathrm{T})$ and infinitesimal $\left(\mathrm{r}_{\mathrm{m}}\right)$ and finite $(\lambda)$ rates of population increase (Southwood, 1978; Maia et al., 2000).

The aim of the present study was to evaluate parameters of fertility and life expectancy tables for the predator $S$. cincticeps exposed to sublethal doses of permethrin during third instar.

\section{MATERIAL AND METHODS}

This research was conducted in the Biological Control Laboratory of the "Centro de Biotecnologia Aplicada à Agropecuária (BIOAGRO)" of the Federal University of Viçosa (UFV)", Municipality of Viçosa, State of Minas Gerais, Brazil at $25 \pm 0.5^{\circ} \mathrm{C}, 75 \pm 5 \% \mathrm{RH}$ and a 12 -hour photoperiod.

Zeneca Agro (Holambra, SP, Brazil) supplied the technical grade (96\% pure) permethrin used, and the acetone (pa) was purchased from Isolar Ltda (Jacaré, RJ, Brazil). The permethrin was diluted in acetone to obtain the doses of $5.74 \times 10^{-3}$, $5.74 \times 10^{-2}, 5.74 \times 10^{-1}, 5.74$, and $57.44 \mathrm{ppb}$ based on $\mathrm{mg}$ a.i./ $\mathrm{mg}$ of wet weight of $S$. cincticeps and acetone in the control treatment.

A total of 450 second instar nymphs of $S$. cincticeps was obtained from eggs of the mass rearing facility of the UFV Biological Control Laboratory where groups of ten individuals were placed in Petri dishes (9.0 $\mathrm{x} 1.2 \mathrm{~cm}$ ) with a moist cotton ball and fed ad lib with Tenebrio molitor L. (Coleoptera: Tenebrionidae) pupae from this laboratory. At the beginning of third instar, $75 \mathrm{~S}$. cincticeps nymphs per treatment were placed individual in plastic cups $(40 \mathrm{ml})$. These nymphs were raised until adult stage with $T$. molitor pupae, and water was supplied in $2 \mathrm{ml}$ cylindrical tubes inserted in a circular $0.9 \mathrm{~mm}$ hole in the cover of the plastic cups with its lower end closed with a cotton ball to avoid water flowing. Each $S$. cincticeps nymph received $1 \mu l$ of the insecticide solution topically applied on its dorsum with a calibrated micro syringe according to the treatment and acetone in the control.

Pairs of $S$. cincticeps adults (one male and one female) were isolated in transparent plastic cups $(500 \mathrm{ml})$ totaling $27,30,33,27,27$, and 24 pairs for the doses of $5.74 \times 10^{-3}, 5.74 \times 10^{-2}, 5.74 \times 10^{-1}$, $5.74,57.44 \mathrm{ppb}$ and in the control, respectively with water and $T$. molitor pupae.

Mortality and longevity of females, number of egg masses, eggs, and nymphs, as well as periods of preoviposition, egg laying, and egg incubation were recorded daily. These data were grouped into age classes of seven days and used to elaborate fertility and life expectancy tables during one generation of $S$. cincticeps. Average and standard error of the number of eggs per female were calculated daily for each age class. Egg viability was obtained per egg mass of this predator.

$S$. cincticeps fertility tables were compiled at each age interval (x) and included specific fertility $\left(\mathrm{m}_{\mathrm{x}}\right)$ (number of females produced per survival female at age interval $\mathrm{x}$ ); survival rate $\left(\mathrm{l}_{\mathrm{x}}\right)$ (survival from age zero to the beginning of age $\mathrm{x}$ ); gross reproductive rate (GRR) net reproductive rate $\left(\mathrm{R}_{0}\right)$; generation time $(\mathrm{T})$; doubling time (DT); infinitesimal $\left(r_{\mathrm{m}}\right)$ and finite $(\lambda)$ rates of population increase; and reproductive value $(\mathrm{RVx})$ (contribution of a female of age $x$ for the future population) (Southwood, 1978, Krebs, 1994).

The life $S$. cincticeps expectancy table was compiled with numbers of survivors at the beginning of age $\mathrm{x}\left(\mathrm{L}_{\mathrm{x}}\right)$; number of individuals that died during age $\mathrm{x}\left(\mathrm{d}_{\mathrm{x}}\right)$; survival rate during age $\mathrm{x}\left(\mathrm{S}_{\mathrm{x}}\right)$; survival from age zero to the beginning of age $\mathrm{x}\left(1_{\mathrm{x}}\right)$; mortality at age interval $\mathrm{x}\left(\mathrm{q}_{\mathrm{x}}\right)$; and life expectancy $\left(\mathrm{e}_{\mathrm{x}}\right)$. These parameters were used to estimate regression curves for $S$. cincticeps as a function of life expectancy for half of the population (ex50) of this 
predator by probit analysis (Finney, 1971) with SAS Proc Probit (SAS, 1989). Data on the different treatments were compared with the program developed by Maia et al. (2000).

\section{RESULTS}

Females $S$. cincticeps started oviposition at age 35 days with the most sublethal doses of permethrin (Fig. 1) with gross reproductive rate (40.80 females per female) and higher net reproductive rate (R0) (18.31 females per female) with the dose of $5.74 \times 10^{-1} \mathrm{ppb}$ of permethrin than in the control (Tables I and II). Maximum reproductive values ( $R V x)$ of $S$. cincticeps were registered at age class six with the doses of $5.74 \times 10-1 \mathrm{ppb}$ and in the control (Table II).

Generation time (T) of $S$. cincticeps varied from 57.93 days with $5.74 \times 10^{-1} \mathrm{ppb}$ to 59.25 days with $5.74 \mathrm{ppb}$ of permethrin, while this value was 59.49 days in the control (Table I), which indicates five generations per year of $S$. cincticeps.
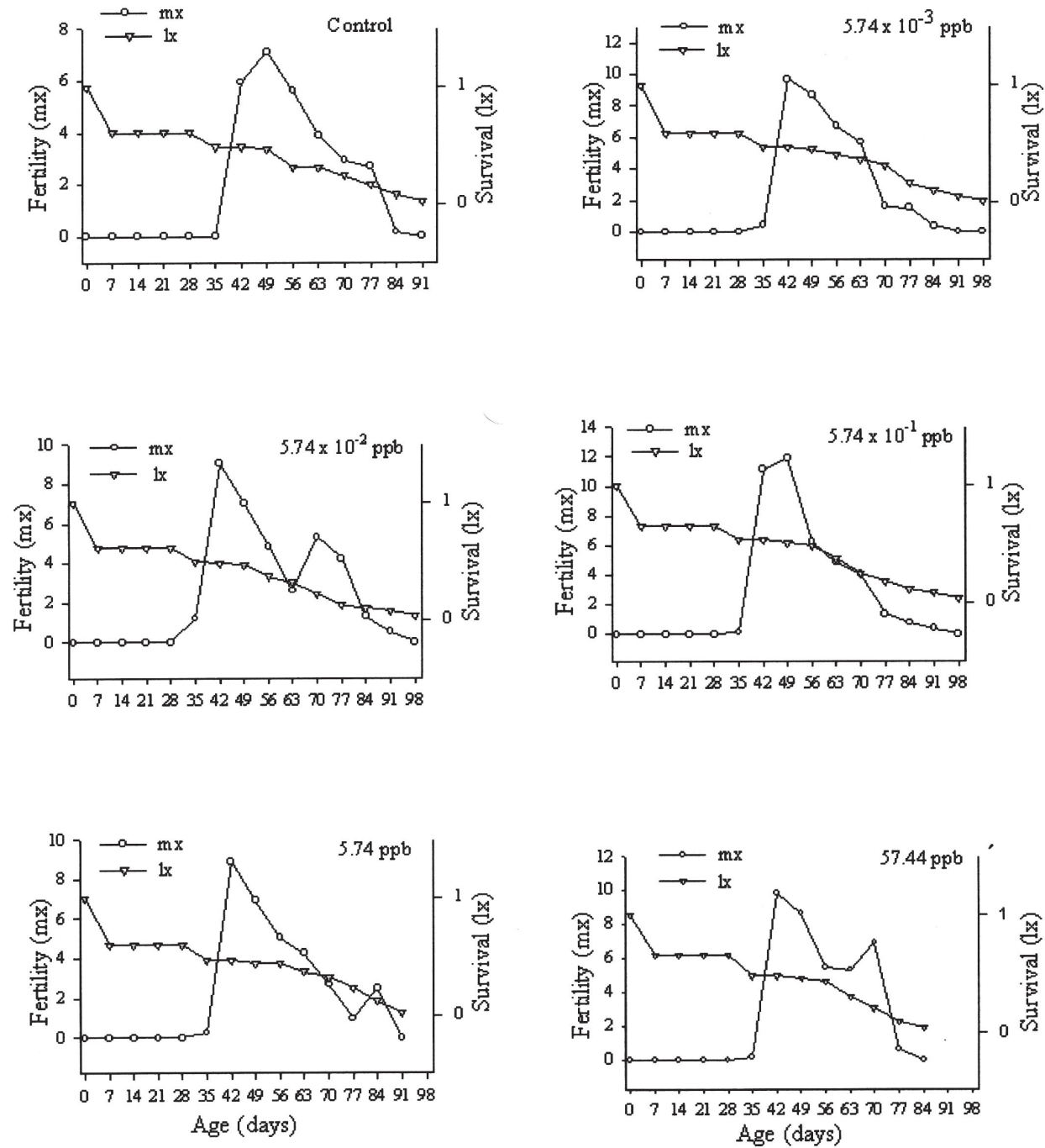

Figure 1. Fertility $\left(\mathrm{m}_{\mathrm{x}}\right)$ and survival $\left(\mathrm{l}_{\mathrm{x}}\right)$ of Supputius cincticeps (Heteroptera: Pentatomidae) topically exposed to five sublethal doses of permethrin during the third instar and in the control at $25 \pm 1{ }^{\circ} \mathrm{C}, 75 \pm 10 \% \mathrm{RH}$, and a 12-hour photoperiod. 


\section{TABLE I}

Life table parameters of Supputius cincticeps (Heteroptera: Pentatomidae) topically exposed to five doses of permethrin during the third instar and in the control at $25 \pm 1{ }^{\circ} \mathrm{C}$, $75 \pm 10 \% \mathrm{RH}$, and a 12-hour photoperiod

\begin{tabular}{clllll}
\hline Doses $(\mathrm{ppb})$ & $\mathrm{R}_{\mathrm{o}}$ & $\mathrm{T}$ & $\mathrm{DT}$ & $\mathrm{r}_{\mathrm{m}}$ & $\lambda$ \\
\hline Control & $10.32 \mathrm{~b}$ & $59.49 \mathrm{a}$ & $17.77 \mathrm{~b}$ & $0.040 \mathrm{~b}$ & $1.040 \mathrm{~b}$ \\
$5.74 \times 10^{-3}$ & $14.08 \mathrm{ab}$ & $58.21 \mathrm{ab}$ & $15.40 \mathrm{ab}$ & $0.045 \mathrm{a}$ & $1.046 \mathrm{a}$ \\
$5.74 \times 10^{-2}$ & $12.66 \mathrm{ab}$ & $58.30 \mathrm{ab}$ & $15.75 \mathrm{ab}$ & $0.045 \mathrm{a}$ & $1.045 \mathrm{ab}$ \\
$5.74 \times 10^{-1}$ & $18.31 \mathrm{a}$ & $57.93 \mathrm{c}$ & $13.86 \mathrm{a}$ & $0.050 \mathrm{a}$ & $1.051 \mathrm{a}$ \\
5.74 & $12.54 \mathrm{ab}$ & $59.25 \mathrm{a}$ & $16.12 \mathrm{ab}$ & $0.043 \mathrm{ab}$ & $1.044 \mathrm{ab}$ \\
57.44 & $14.18 \mathrm{ab}$ & $58.44 \mathrm{ab}$ & $15.40 \mathrm{ab}$ & $0.045 \mathrm{a}$ & $1.046 \mathrm{a}$ \\
\hline
\end{tabular}

$\mathrm{R}_{\mathrm{O}}=$ net reproductive rate; $\mathrm{T}=$ generation time (days); $\mathrm{DT}=$ doubling time (days); $\mathrm{rm}=$ infinitesimal rate of increase; $\lambda=$ finite rate of increase. Means followed by the same letter in the column do not differ significantly by Student $t$ test $(\mathrm{P}=0.05)$

\section{TABLE II}

Fertility life table for Supputius cincticeps (Heteroptera: Pentatomidae) topically exposed to five doses of permethrin during the third instar and in the control at $25 \pm 1{ }^{\circ} \mathrm{C}, 75 \pm 10 \%$ $\mathrm{RH}$, and a 12-hour photoperiod

\begin{tabular}{|c|c|c|c|c|c|c|c|c|}
\hline Doses (ppb) & $\mathrm{X}$ & $\mathrm{L}_{\mathrm{x}}$ & $1_{\mathrm{x}}$ & $\mathrm{m}_{\mathrm{x}}$ & $1_{x} \cdot m_{x}$ & $\mathrm{x} \cdot \mathrm{1}_{\mathrm{x}} \cdot \mathrm{m}_{\mathrm{x}}$ & $\mathrm{RV}_{\mathrm{x}}$ & Stage \\
\hline \multirow[t]{14}{*}{ Control } & 1 & 109 & 1.00 & 0.00 & 0.00 & 0.00 & 4.64 & \multirow[t]{5}{*}{ Nymphs } \\
\hline & 2 & 75 & 0.69 & 0.00 & 0.00 & 0.00 & 6.74 & \\
\hline & 3 & 75 & 0.69 & 0.00 & 0.00 & 0.00 & 6.74 & \\
\hline & 4 & 75 & 0.69 & 0.00 & 0.00 & 0.00 & 6.74 & \\
\hline & 5 & 75 & 0.69 & 0.00 & 0.00 & 0.00 & 6.74 & \\
\hline & 6 & 24 & 0.22 & 0.00 & 0.00 & 0.00 & 21.06 & \multirow{9}{*}{ Adult } \\
\hline & 7 & 24 & 0.22 & 5.93 & 1.30 & 9.13 & 21.06 & \\
\hline & 8 & 23 & 0.21 & 7.11 & 1.50 & 12.01 & 15.80 & \\
\hline & 9 & 15 & 0.14 & 5.61 & 0.77 & 6.95 & 13.31 & \\
\hline & 10 & 15 & 0.14 & 3.89 & 0.54 & 5.35 & 7.70 & \\
\hline & 11 & 12 & 0.11 & 2.92 & 0.32 & 3.54 & 4.77 & \\
\hline & 12 & 8 & 0.07 & 2.68 & 0.20 & 2.36 & 2.77 & \\
\hline & 13 & 4 & 0.04 & 0.17 & 0.01 & 0.08 & 0.17 & \\
\hline & 14 & 1 & 0.01 & 0.00 & 0.00 & 0.00 & 0.00 & \\
\hline \multirow[t]{15}{*}{$5.74 \times 10^{-3}$} & 1 & 119 & 1.00 & 0.00 & 0.00 & 0.00 & 6.86 & \multirow[t]{5}{*}{ Nymphs } \\
\hline & 2 & 75 & 0.63 & 0.00 & 0.00 & 0.00 & 10.89 & \\
\hline & 3 & 75 & 0.63 & 0.00 & 0.00 & 0.00 & 10.89 & \\
\hline & 4 & 75 & 0.63 & 0.00 & 0.00 & 0.00 & 10.89 & \\
\hline & 5 & 75 & 0.63 & 0.00 & 0.00 & 0.00 & 10.89 & \\
\hline & 6 & 27 & 0.23 & 0.43 & 0.10 & 0.59 & 30.25 & \multirow[t]{10}{*}{ Adult } \\
\hline & 7 & 27 & 0.23 & 9.68 & 2.20 & 15.38 & 29.82 & \\
\hline & 8 & 26 & 0.22 & 8.70 & 1.90 & 15.21 & 20.91 & \\
\hline & 9 & 23 & 0.19 & 6.68 & 1.29 & 11.62 & 13.80 & \\
\hline & 10 & 21 & 0.18 & 5.69 & 1.00 & 10.04 & 7.79 & \\
\hline & 11 & 18 & 0.15 & 1.59 & 0.24 & 2.64 & 2.46 & \\
\hline & 12 & 9 & 0.08 & 1.49 & 0.11 & 1.35 & 1.74 & \\
\hline & 13 & 6 & 0.05 & 0.37 & 0.02 & 0.24 & 0.37 & \\
\hline & 14 & 3 & 0.03 & 0.00 & 0.00 & 0.00 & 0.00 & \\
\hline & 15 & 1 & 0.01 & 0.00 & 0.00 & 0.00 & 0.00 & \\
\hline \multirow[t]{3}{*}{$5.74 \times 10^{-2}$} & 1 & 111 & 1.00 & 0.00 & 0.00 & 0.00 & 6.85 & \multirow[t]{3}{*}{ Nymphs } \\
\hline & 2 & 75 & 0.68 & 0.00 & 0.00 & 0.00 & 10.13 & \\
\hline & 3 & 75 & 0.68 & 0.00 & 0.00 & 0.00 & 10.13 & \\
\hline
\end{tabular}


Table II. Continuación

\begin{tabular}{|c|c|c|c|c|c|c|c|c|}
\hline Doses (ppb) & $\mathrm{x}$ & $\mathrm{L}_{\mathrm{x}}$ & $1_{\mathrm{x}}$ & $\mathrm{m}_{\mathrm{x}}$ & $1_{x} \cdot m_{x}$ & $\mathrm{x} \cdot \mathrm{l}_{\mathrm{x}} \cdot \mathrm{m}_{\mathrm{x}}$ & $\mathrm{RV}_{\mathrm{x}}$ & Stage \\
\hline & 4 & 75 & 0.68 & 0.00 & 0.00 & 0.00 & 10.13 & \\
\hline & 5 & 75 & 0.68 & 0.00 & 0.00 & 0.00 & 10.13 & \\
\hline & 6 & 30 & 0.27 & 1.20 & 0.32 & 1.95 & 25.33 & Adult \\
\hline & 7 & 29 & 0.26 & 9.04 & 2.36 & 16.53 & 24.96 & \\
\hline & 8 & 28 & 0.25 & 7.03 & 1.77 & 14.18 & 16.49 & \\
\hline & 9 & 22 & 0.20 & 4.85 & 0.96 & 8.65 & 12.05 & \\
\hline & 10 & 19 & 0.17 & 2.61 & 0.45 & 4.47 & 8.34 & \\
\hline & 11 & 13 & 0.12 & 5.33 & 0.62 & 6.87 & 8.37 & \\
\hline & 12 & 7 & 0.06 & 4.21 & 0.27 & 3.19 & 5.63 & \\
\hline & 13 & 6 & 0.05 & 1.31 & 0.07 & 0.92 & 1.66 & \\
\hline & 14 & 4 & 0.04 & 0.53 & 0.02 & 0.27 & 0.53 & \\
\hline & 15 & 2 & 0.02 & 0.00 & 0.00 & 0.00 & 0.00 & \\
\hline \multirow[t]{15}{*}{$5.74 \times 10^{-1}$} & 1 & 105 & 1.00 & 0.00 & 0.00 & 0.00 & 10.64 & Nymphs \\
\hline & 2 & 75 & 0.71 & 0.00 & 0.00 & 0.00 & 14.89 & \\
\hline & 3 & 75 & 0.71 & 0.00 & 0.00 & 0.00 & 14.89 & \\
\hline & 4 & 75 & 0.71 & 0.00 & 0.00 & 0.00 & 14.89 & \\
\hline & 5 & 75 & 0.71 & 0.00 & 0.00 & 0.00 & 14.89 & \\
\hline & 6 & 33 & 0.31 & 0.12 & 0.04 & 0.23 & 33.85 & Adult \\
\hline & 7 & 33 & 0.31 & 11.14 & 3.50 & 24.51 & 33.72 & \\
\hline & 8 & 31 & 0.30 & 11.92 & 3.52 & 28.16 & 24.04 & \\
\hline & 9 & 29 & 0.28 & 6.24 & 1.72 & 15.51 & 12.95 & \\
\hline & 10 & 23 & 0.22 & 4.89 & 1.07 & 10.71 & 8.46 & \\
\hline & 11 & 15 & 0.14 & 4.02 & 0.57 & 6.31 & 5.48 & \\
\hline & 12 & 11 & 0.10 & 1.34 & 0.14 & 1.68 & 1.99 & \\
\hline & 13 & 7 & 0.07 & 0.77 & 0.05 & 0.67 & 1.03 & \\
\hline & 14 & 5 & 0.05 & 0.37 & 0.02 & 0.24 & 0.37 & \\
\hline & 15 & 2 & 0.02 & 0.00 & 0.00 & 0.00 & 0.00 & \\
\hline \multirow[t]{14}{*}{5.74} & 1 & 114 & 1.00 & 0.00 & 0.00 & 0.00 & 6.27 & Nymphs \\
\hline & 2 & 75 & 0.66 & 0.00 & 0.00 & 0.00 & 9.53 & \\
\hline & 3 & 75 & 0.66 & 0.00 & 0.00 & 0.00 & 9.53 & \\
\hline & 4 & 75 & 0.66 & 0.00 & 0.00 & 0.00 & 9.53 & \\
\hline & 5 & 75 & 0.66 & 0.00 & 0.00 & 0.00 & 9.53 & \\
\hline & 6 & 27 & 0.24 & 0.27 & 0.06 & 0.38 & 26.47 & Adult \\
\hline & 7 & 27 & 0.24 & 8.91 & 2.11 & 14.77 & 26.21 & \\
\hline & 8 & 25 & 0.22 & 6.93 & 1.52 & 12.15 & 18.68 & \\
\hline & 9 & 25 & 0.22 & 5.05 & 1.11 & 9.96 & 11.76 & \\
\hline & 10 & 21 & 0.18 & 4.26 & 0.79 & 7.85 & 7.99 & \\
\hline & 11 & 18 & 0.16 & 2.69 & 0.42 & 4.67 & 4.35 & \\
\hline & 12 & 13 & 0.11 & 0.96 & 0.11 & 1.31 & 2.30 & \\
\hline & 13 & 7 & 0.06 & 2.49 & 0.15 & 1.98 & 2.49 & \\
\hline & 14 & 1 & 0.01 & 0.00 & 0.00 & 0.00 & 0.00 & \\
\hline \multirow[t]{13}{*}{57.44} & 1 & 119 & 1.00 & 0.00 & 0.00 & 0.00 & 6.67 & Nymphs \\
\hline & 2 & 75 & 0.63 & 0.00 & 0.00 & 0.00 & 10.59 & \\
\hline & 3 & 75 & 0.63 & 0.00 & 0.00 & 0.00 & 10.59 & \\
\hline & 4 & 75 & 0.63 & 0.00 & 0.00 & 0.00 & 10.59 & \\
\hline & 5 & 75 & 0.63 & 0.00 & 0.00 & 0.00 & 10.59 & \\
\hline & 6 & 27 & 0.23 & 0.15 & 0.03 & 0.20 & 29.41 & Adult \\
\hline & 7 & 27 & 0.23 & 9.87 & 2.24 & 15.68 & 29.27 & \\
\hline & 8 & 26 & 0.22 & 8.61 & 1.88 & 15.06 & 20.14 & \\
\hline & 9 & 24 & 0.20 & 5.43 & 1.09 & 9.85 & 12.49 & \\
\hline & 10 & 17 & 0.14 & 5.30 & 0.76 & 7.57 & 9.97 & \\
\hline & 11 & 11 & 0.09 & 6.93 & 0.64 & 7.05 & 7.21 & \\
\hline & 12 & 5 & 0.04 & 0.61 & 0.03 & 0.31 & 0.61 & \\
\hline & 13 & 2 & 0.02 & 0.00 & 0.00 & 0.00 & 0.00 & \\
\hline
\end{tabular}

$\mathrm{x}=$ age $(\mathrm{x}=$ seven days $) ; \mathrm{L}_{\mathrm{x}}=$ number of survivors at the beginning of age $\mathrm{x} ; \mathrm{m}_{\mathrm{x}}=$ number of females produced per female of age $x ; 1_{x}=$ survival rate from age zero to the beginning of age $x ; V_{x}=$ reproduction value of age $x$. 
The time necessary for this predator to double its population (DT) was 13.86 days with the doses of $5.74 \times 10^{-1} \mathrm{ppb}$ of permethrin, which was shorter than in the control (Table I).

The infinitesimal rate of population increase $(\mathrm{rm})$ for $S$. cincticeps was 0.04 individuals per day in the control group and 0.05 with the dose of $5.74 \times 10^{-1} \mathrm{ppb}$ dose of permethrin (Table I), while the finite rate of population increase $(\lambda)$ was 1.04 and 1.05 females added to the population per day per $S$. cincticeps female in these treatments.

Fertility curves showed maximum reproduction of $S$. cincticeps when this predator was 35 to 56 days old with all permethrin doses (Fig. 1).

Survival curves $\left(1_{x}\right)$ declined until day 7 followed by a period of similar mortality (age classes 7 to 28 days) (Fig. 1). The slope of survival curves was similar with all doses of permethrin, and it decreased with the age of the predator (Fig. 1).

Life expectancy showed that $S$. cincticeps can live up to 105 days with the doses of $5.74 \times 10^{-2}, 5.74 \times 10^{-1}$, and 5.74 ppb, and 91 days in the control. Average life expectancy $\left(\mathrm{ex}_{50}\right)$ for half of the $S$. cincticeps population with all permethrin doses showed higher mortality and average life expectancy $\left(\mathrm{ex}_{50}\right)$ at each age interval with $5.74 \mathrm{ppb}$ of permethrin when analyzed by probit (42.6 days) (Table III and Fig. 2).

\section{DISCUSSION}

The of $5.74 \times 10^{-1} \mathrm{ppb}$ dose of permethrin stimulated population increase in $S$. cincticeps with higher $\mathrm{R}_{0}$ (18.31 females/ female), $\mathrm{RV}_{\mathrm{x}}$ (33.85) and lower $\mathrm{T}$ (57.93 days) values, which indicate the occurrence of hormesis with this sublethal dose of permethrin (Calabrese, 1999; Forbes, 2000, Zanuncio, et al., 2003) and GRR of 40.80 females per female. The R0 supplies more precise values than the GRR because it incorporates mortality rate during young and adult stages of organisms (Force and Messenger, 1964). Predators used in pest management should present higher reproduction values, and their oviposition peaks should coincide with the necessity of pest control. Moreover, low $\mathrm{T}$ values are important for natural enemies in the laboratory where it is necessary to obtain a higher number of generations per time to compensate for the lower values of $R_{0}$ and $r_{m}$. The $R_{0}$ is less reliable for comparing populations of organisms because the generation time differs between species and it may not express the real capacity of a species to increase in numbers (Price, 1997). Therefore the $\mathrm{rm}$ is more commonly used to compare populations of organisms under different conditions because it relates net reproductive rate $\left(\mathrm{R}_{0}\right)$ with generation time (T). Furthermore, lower differences

\section{TABLE III}

Probit analysis of life expectancy as function of survival of Supputius cincticeps (Heteroptera: Pentatomidae) topically exposed to five doses of permethrin during the third instar and in the control at $25 \pm 1{ }^{\circ} \mathrm{C}, 75 \pm 10 \% \mathrm{RH}$, and a 12-hour photoperiod

\begin{tabular}{llllll}
\hline & \multicolumn{3}{l}{ Characteristics } \\
\cline { 2 - 5 } Doses & Equation & Probability & & \\
& & $\chi^{2}$ & & \\
of $\chi^{2}$ & & & IC (95\%) (days) \\
Control & $\mathrm{Y}^{\prime}=2.6280-0.0732 \times$ & 1.00 & 13.81 & 35.8 & $(34.74-37.05)$ \\
$5.74 \times 10^{-3}$ & $\mathrm{Y}^{\prime}=2.8128-0.0722 \times$ & 1.00 & 16.56 & 38.9 & $(37.91-40.04)$ \\
$5.74 \times 10^{-2}$ & $\mathrm{Y}^{\prime}=2.1350-0.0602 \times$ & 0.99 & 45.52 & 35.4 & $(34.30-36.53)$ \\
$5.74 \times 10^{-1}$ & $\mathrm{Y}^{\prime}=2.4991-0.0662 \times$ & 1.00 & 22.53 & 37.7 & $(36.72-38.76)$ \\
5.74 & $\mathrm{Y}^{\prime}=2.6328-0.0617 \times$ & 1.00 & 15.99 & 42.6 & $(41.43-43.82)$ \\
57.44 & $\mathrm{Y}^{\prime}=2.2179-0.0672 \times$ & 1.00 & 22.10 & 33.2 & $(32.31-34.14)$ \\
\hline
\end{tabular}

$\mathrm{IC}=$ Reliability interval $\left(\mathrm{ex}_{50}\right)$ at $95 \%$ probability; $\mathrm{X}^{2}=$ Qui-square; $\mathrm{Y}^{\prime}=$ life expectancy in "probit" and $\mathrm{x}=$ survival $(\%)$ in decimal logarithm. 

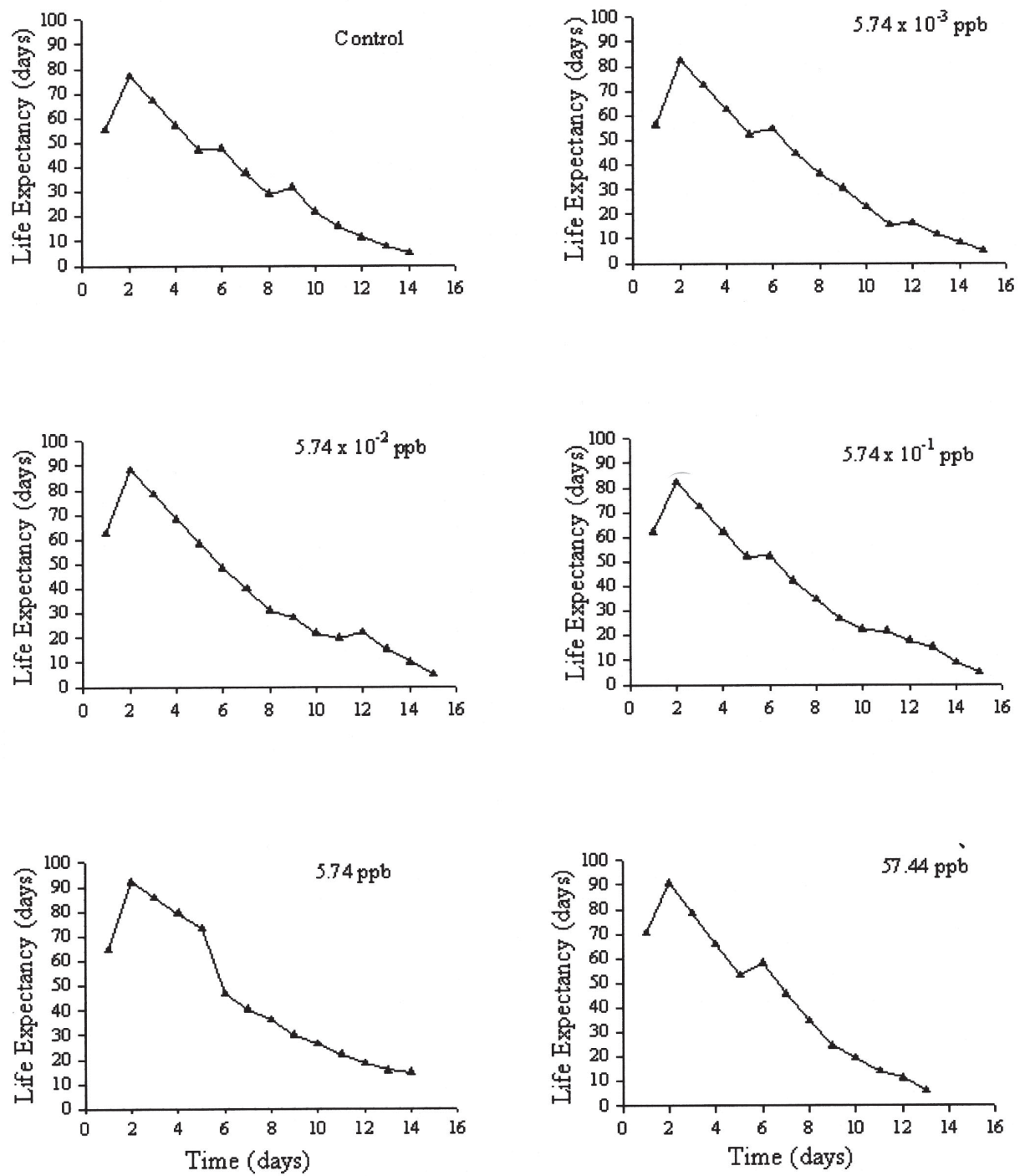

Figure 2. Life expectancy of Supputius cincticeps (Heteroptera: Pentatomidae) topically exposed to five sublethal doses of permethrin during the third instar and in the control at $25 \pm 1{ }^{\circ} \mathrm{C}, 75 \pm 10 \% \mathrm{RH}$, and a 12-hour photoperiod.

between treatments are not necessarily an indication of similarity because low variations in these numbers can lead to high differences in total values of individuals of a population (Silveira Neto et al., 1976).

Supputius cincticeps showed similar values for $\mathrm{T}$ and $\mathrm{rm}$ with the doses of $5.74 \mathrm{x}$ $10^{-1} \mathrm{ppb}$ of permethrin to those of Assis et al. (1998) with this predator. These values can differ between Asopinae species because $\mathrm{R}_{0}, \mathrm{~T}$ and $\mathrm{r}_{\mathrm{m}}$ of Tynacantha marginata (Dallas) (Heteroptera: Pentatomidae) were 50.68, 69.09 and 1.48, respectively (Moreira et al., 1995).

The best age to release female predators in agro ecosystems for pest control can be defined according to their reproductive values $\left(\mathrm{RV}_{\mathrm{x}}\right)$. $S$. cincticeps showed a higher reproductive value (33.85) after 42 days with $5.74 \times 10^{-1} \mathrm{ppb}$ of permethrin, which was similar to that reported for Podisus nigrispinus (Dallas) (Heteroptera: Pentatomidae) (Medeiros et al., 2000). 
These results are important for biological control programs where pests are controlled by the progeny of individuals released (De Bach and Hagen, 1964). Specific fertility curves $\left(\mathrm{m}_{\mathrm{x}}\right)$ showed that $S$. cincticeps females start to reproduce at 28 days, with a higher tendency for population increase when they reach 36 to 42 days.

The $S$. cincticeps survival curve $\left(1_{\mathrm{x}}\right)$ for all permethrin doses and the control was type II according to the Rabinovich classification (1978). This curve represents a population with constant number of deaths per unit of time and with a straight line and similar increment on mortality for young and old individuals.

Life expectancy $\left(\mathrm{e}_{\mathrm{x}}\right)$ for $S$. cincticeps varied with permethrin doses with higher values in the column risk $\left(\mathrm{q}_{\mathrm{x}}\right)$, which indicates the probability that an individual will die before the time established in the column $e_{x}$ (Southwood, 1978). Life expectancy decreased with adult age of this predator in all treatments except with the $5.74 \mathrm{ppb}$ dose of permethrin, which showed a longer life expectancy (42.6 days) and better survival rate for $S$. cincticeps.

The insecticide permethrin was selective with all sublethal doses applied, which is desirable for natural enemies and can stimulate population increase of $S$. cincticeps. This predator can present adequate performance in integrated pest management when exposed to sublethal doses of permethrin.

\section{ACKNOWLEDGEMENTS}

We would like to extend our thanks to the following Brazilian agencies: Conselho Nacional de Desenvolvimento Científico e Technológico (CNPq), Coordenação de Aperfeiçoamento de Pessoal de Nível Superior (CAPES), and Fundação de Amparo à Pesquisa do Estado de Minas Gerais (FAPEMIG).

\section{REFERENCES}

ASSIS JR SL, ZANUNCIO TV, SANTOS GP, ZANUNCIO JC (1998) Efeito da suplementação de folhas de Eucalyptus urophylla no desenvolvimento e reprodução de Supputius cincticeps (Stål. 1860)
(Heteroptera: Pentatomidae). An Soc Entomol Brasil 27: 245-253

BATALHA VC, ZANUNCIO JC, PICANÇO MC, SEDIYAMA CS (1995) Seletividade de inseticidas aos predadores Podisus nigrispinus (Dallas. 1851) e Supputius cincticeps (Stål. 1860) (Heteroptera: Pentatomidae) e a sua presa Lepidoptera. Rev Árvore 19: 382-395

BATALHA VC, ZANUNCIO JC, PICANÇO MC, GUEDES RNC (1997) Selectivity of inseticides to Podisus nigrispinus (Heteroptera: Pentatomidae) and its prey Spodoptera frugiperda (Lepidoptera: Noctuidae). Ceiba 38: 19-22

CALABRESE EJ, BALDWIN LA (1997a) The dose makes the stimulation (and the poison). Int J Toxico. 16: 545-559

CALABRESE EJ, BALDWIN LA (1997b) A quantitatively-based methodology for the evaluation of chemical hormesis. Human Ecol Risk Asses 3: 545-554

CALABRESE EJ (1999) Evidence that hormesis represents an "overcompensation" response to a disruption in homeostasis. Ecot Environ Safety 42: 135-137

CONTRERAS VT, NAVARRO MC, DE LIMA AR, DURÁN F, ARTEGA R, FRANCO Y (2002) Early and late molecular and morphologic changes that occur during the in vitro transformation of Trypanosoma cruzi metacyclic trypomastigotes to amastigotes. Biol Res 35:47-58

DE BACH P, HAGEN KS (1964) Manipulation of entomophagous species. In: DE BACH P (ed.) Biological control of insect pest and weeds. London: Chapman \& Hall. pp: 429-458

ELLIOT M, JANES NE, POTTER C (1978) The future of pyrethroids in insect control. An Rev Entomol 23: 443-469

FINNEY DJ (1971) Probit analysis. $3^{\text {rd }}$ ed. London: Cambridge University Press

FORBES VE (2000) Is hormesis an evolutionary expectation? Func Ecol 14: 12-24

FORCE DC, MESSENGER PS (1964) Fecundity, reproductive rates and innate capacity for increase of three parasites of Therioaphis maculata (Buckton). Ecol 45: 706-715

GUEDES RNC, LIMA JOG, ZANUNCIO JC (1992) Seletividade dos inseticidas deltametrina. fenvalerato e fenitrotion para Podisus connexivus (Heteroptera: Pentatomidae). An Soc Entomol Brasil 21: 339-346

KREBS CJ (1994) Ecology: the experimental analysis of distribution and abundance. $4^{\text {th }}$ ed. New York: Harper Collins College Publishers

LUSTOSA PR, ZANUNCIO JC, LEITE, GLD, PICANÇO MC (1999) Qualidade da semente e senescência de genótipos de soja sob dois níveis de infestação de percevejos (Pentatomidae). Pesq Agrop Brasil 34: 1347-1351. 1999

MAIA ALINE DE HN, ALFREDO JB, CAMPANHOLA C (2000) Statistical inference on associated fertility life table parameters using Jackknife technique: Computational Aspects. J Econ Entomol 93: 511-518

MATOS FCM, OLIVEIRA HN, ZANUNCIO JC, HOLTZ A, OLIVEIRA I., FIALHO MCQ (2004a) Ganancia de peso del depredador Podisus distinctus (Het.: Pentatomidae) en combinaciones de las presas Tenebrio molitor (Col.: Tenebrionidae) y Musca domestica (Dip.: Muscidae). Rev Biol Trop 52: 101-108

MATOS NETO FC, ZANUNCIO JC, CRUZ I., GUEDES RNC, PICANÇO MC (2004b) Progeny production and parasitism by Campoletis flavicincta (Hym.: Ichneumonidae) as affected by female ageing. Biol Agric Hort 22: 369-378. 2004.

MCPHERSON JE (1982) The Pentatomoidea (Hemiptera) of Northeastern North America. Carbondale and Edwardsville, IL: South Illinois University Press 
MEDEIROS RS, RAMALHO FS, LEMOS WP, ZANUNCIO JC (2000) Age-dependent fecundity and life-tables for Podisus nigrispinus (Dallas) (Het. Pentatomidae). J Appl Entomol 124: 319-324

MOREIRA LA, ZANUNCIO JC, PICANÇO MC, BRUCKNER CH (1995) Tabelas de fertilidade e esperança de vida de Thynacantha marginata Dallas (Heteroptera: Pentatomidae) alimentado com larvas de Tenebrio molitor L. (Coleoptera: Tenebrionidae) e folhas de Eucalyptus urophylla ST Blake. Rev Bras Zool 12: 255-261

PICANÇO MC, GUEDES RNC, BATALHA VC, CAMPOS RP (1996) Toxicity of insecticides to 'Dione juno juno (Lepidoptera: Heliconidae) and selectivity to two of its predaceous bugs. Trop Sci 36: 51-53

PREE DJ, HAGLEY EAC (1985) Toxicity of pesticides to 'Chrysopa oculata Say (Neuroptera: Chrysopidae). 'J Econ Entomol 78: 129-132

PRICE PW (1997) Insect ecology. $3^{\text {rd }}$ ed. New York: John Wiley \& Sons

RABINOVICH JE (1978) Ecologia de poplaciones animales. Washington: Secretaria General de la Organización de los Estados Americanos.

RAJAKULENDRAN SV, PLAPP JR. FW (1982) Comparative toxicities of five synthetic pyrethroids to the tobacco budworm (Lepidoptera: Noctuidae). an Ichneumonidae parasite, Campoletis sonorensis, and a predator, Chrysopa carnea. J Econ Entomol 75: 769-772

SAS INSTITUTE (1989) User's Guide. Version 6. $4^{\text {th }}$ ed. Cary, NC: SAS Institute

SILVEIRA NETO S, NAKANO O, BARDINI D (1976) Manual de ecologia de insetos. São Paulo: Agronômica Ceres

SOUTHWOOD TRE (1978) Ecological methods with particular reference to the study of insect populations. $2^{\text {nd }}$ ed. London: Chapman and Hall
SUINAGA FA, PICANCCO MC, ZANUNCIO JC, BASTOS CS (1996) Seletividade fisiológica de inseticidas a Podisus nigrispinus (Dallas, 1851) (Heteroptera: Pentatomidae) predador de lagartas desfolhadoras de eucalipto. Rev Árvore 20: 407414

UZCANGA G, GALÁN-CARIDAD JM, SUÁREZ KN, BUBIS J (2003) Divalent cation hinder the solubilization of a tubulin kinase activity from Trypanosoma cruzi pimastigotes. Biol Res 36: 367379

YU SJ (1988) Selectivity of insecticides to the spined soldier bug (Heteroptera: Pentatomidae) and its lepidopterous prey. J Econ Entomol 81: 119-122

ZANUNCIO JC, ALVES JB, SARTÓRIO RC, LEITE JEM (1992) Métodos para criação de hemípteros predadores de lagartas. An Soc Entomol Brasil 21: 245-251

ZANUNCIO JC, GUEDES RNC, GARCÍA JF, RODRIGUES LA (1993) Impact of two formulations of deltamethrin in aerial application against caterpillars and their predaceous bugs. Med Fac Landbouww Univ Gent 58: 477-481

ZANUNCIO JC, ALVES JB, ZANUNCIO TV, GARCÍA JF (1994) Hemipterous predators of eucalypt defoliator caterpillars. For Ecol Manage 65: 65-73

ZANUNCIO JC, BATALHA VC, GUEDES RNC, PICANÇO MC (1998) Insecticide selectivity to Supputius cincticeps (Stål 1860) (Heteroptera: Pentatomidae) and its prey Spodoptera frugiperda (Lepidoptera: Noctuidae). J Appl Entomol 122: 457460

ZANUNCIO TV, SERRÃO JE, ZANUNCIO JC, GUEDES RNC (2003) Permethrin induced hormesis on the predator Supputius cincticeps (Stål 1860) (Heteroptera: Pentatomidae). Crop Prot 22: 941-947 